\title{
The Serotonergic Inhibitory Postsynaptic Potential in Prepositus Hypoglossi Is Mediated by Two Potassium Currents
}

\author{
Daniel H. Bobker' ${ }^{1}$ and John T. Williams ${ }^{2}$ \\ 1Department of Neurology and 2Vollum Institute, Oregon Health Sciences University, Portland, Oregon 97201
}

Synaptic inhibition mediated by the activation of potassium channels has been reported from several types of neurons. In each case, despite mediation by different neurotransmitters, the $\cdot \mathrm{K}^{+}$conductance underlying the synaptic potential is activated by a $G$ protein and inwardly rectifies. We report here a second $K^{+}$current that contributes to synaptic inhibition. Intracellular recordings were made from guinea pig nucleus prepositus hypoglossi in vitro, where we have described a 5-HT-mediated IPSP. Voltage-clamp analysis of the current induced by applied 5-HT revealed two separate conductances: an inwardly rectifying, rapidly activating $\mathbf{K}^{+}$ current $\left(I_{\mathrm{IR}}\right)$ and an outwardly rectifying, slowly activating $\mathrm{K}^{+}$ current $\left(I_{O R}\right)$. $I_{\mathrm{R}}$ was blocked by extracellular $\mathrm{Ba}^{2+}(200 \mu \mathrm{M})$ and TEA+ $(126 \mathrm{mM}) . I_{\mathrm{OR}}$ was insensitive to this concentration of $\mathrm{Ba}^{2+}$ and $\mathrm{TEA}+$, but was inhibited by $\mathrm{Cd}^{2+}$ and intracellular BAPTA, indicating $\mathrm{Ca}$ dependence.

Single focal electrical stimuli evoked a 5-HT-mediated IPSP, or under voltage clamp, an inhibitory postsynaptic current (IPSC). $\mathrm{Ba}^{2+}$ blocked only a component of this IPSC, which corresponded to the current caused by $l_{\mathrm{IR}}$. When multiple stimuli were applied (to prolong the release of transmitter), the time-dependent current $I_{\text {or }}$ was more fully activated, resulting in an augmentation of the IPSC. We conclude that the IPSC is caused by both currents and that its amplitude can be modulated by the degree to which $I_{\mathrm{OR}}$ is activated. This represents a mechanism by which synaptic responses can be potentiated.

[Key words: 5-HT, inhibitory postsynaptic potential, potassium channels, Ca-dependent $K$ current, inward rectifier, outward rectifier]

Potassium channels are important for neuronal functioning because they maintain resting membrane potential, help regulate repetitive firing and contribute to some postsynaptic potentials (Hille, 1992). Among the latter, a frequently observed response is an IPSP mediated by a $\mathrm{G}$ protcin-coupled $\mathrm{K}^{+}$channel. Such an IPSP has been reported in the heart (muscarinic receptor mediated), hippocampus (GABA $\mathrm{G}_{\mathrm{B}}$ receptor $)$, locus coeruleus $\left(\alpha_{2}\right.$ adrenoceptor), dorsal raphe (5-HT $\mathrm{HA}_{1 \mathrm{~A}}$ receptor), submucous plex-

\footnotetext{
Received Apr. 18, 1994; revised June 13, 1994; accepted June 16, 1994.

This work was supported by USPHS Grants NS 01574 (D.H.B.) and DA 04523 (J.T.W.), and a grant from the National Association for Research on Schizophrenia and Affective Disorders (D.H.B.). We thank Drs. N. Marrion, C. Jahr, and M. Simmons for comments on the experiments and manuscript.

Correspondence should be addressed to Daniel H. Bobker, Department of Neurology, L226, Oregon Health Sciences University, 3181 SW Sam Jackson Park Road, Portland, OR 97201.

Copyright (C) 1995 Society for Neuroscience $0270-6474 / 95 / 150223-07 \$ 05.00 / 0$
}

us (somatostatin receptor), and other regions (Del Castillo and Katz, 1955; Egan et al., 1983; Mihara et al., 1987; Dutar and Nicoll, 1988; North, 1989; Pan et al., 1989). In each example, the inhibitory current is caused by a $\mathrm{K}^{+}$conductance that passes inward current more readily than outward current (inward rectifier or $I_{\mathrm{IR}}$ ), develops rapidly during voltage-clamp steps and is sensitive to inhibition by extracellular barium. Recently, the $\mathrm{K}^{+}$channel coupled to muscarinic receptors in atrial myocytes has been cloned and determined to be a member of a new family of channels (Kubo et al., 1993).

We have observed an IPSP in the guinea pig nucleus prepositus hypoglossi (PH). Previous investigations have demonstrated that the IPSP is caused by $5-\mathrm{HT}_{1 \mathrm{~A}}$ receptor activation, leading to an increase in $\mathrm{K}^{+}$conductance (Bobker and Williams, 1990). In other brain regions, the $5-\mathrm{HT}_{1 \mathrm{~A}}$ receptor has been shown to both activate an inward rectifier $\mathrm{K}^{+}$current (Andrade and $\mathrm{Ni}$ coll, 1987; Williams et al., 1988) and to reduce calcium currents (Pennington and Kelly, 1990). Our voltage-clamp studies in the $\mathrm{PH}$ have revealed that this receptor activates two separable $\mathrm{K}^{+}$ currents: an inward rectifier and a novel, outward rectifier. The purpose of this investigation was to characterize these currents and determine their respective roles in mediating the IPSP.

\section{Materials and Methods}

Intracellular recordings. Slices of brainstem (thickness of $300 \mu \mathrm{m}$ ) from male guinea pigs (200-300 gm) containing the PH (medial medulla) were cut in the horizontal plane in a vibratome, submerged in a $0.5 \mathrm{ml}$ tissue bath and superfused with physiological saline $(1.5 \mathrm{ml} / \mathrm{min})$ at $35^{\circ} \mathrm{C}$. The content of the superfusate was (mм) $\mathrm{NaCl}, 126 ; \mathrm{KCl}, 2.5$ (unless otherwisc stated); $\mathrm{NaH}_{2} \mathrm{PO}_{4}, 1.2 ; \mathrm{MgCl}_{2}, 1.2 ; \mathrm{CaCl}_{2}, 2.4 ;$ glucose, 11 ; and $\mathrm{NaHCO}_{3}, 24$, saturated with $95 \% \mathrm{O}_{2}, 5 \% \mathrm{CO}_{2}$. Microelectrodes were filled with $2 \mathrm{M} \mathrm{KCl}$ and were from $40-80 \mathrm{M} \Omega$ in resistance. Measurement of current and voltage were done with an Axoclamp- $2 \mathrm{~A}$ amplifier and recorded onto CHART (ADInstruments) or pCLAMP (Axon Instruments). Voltage-clamp experiments were done with a discontinuous single-electrode voltage clamp (sample rate $2-6 \mathrm{kHz}$, filtered at $0.1 \mathrm{kHz}$ ) with continuous monitoring of the headstage for adequacy of the clamp. Intracellular filling of cells with BAPTA was done by either adding it to the microelectrode solution (50-100 mM with $2 \mathrm{M} \mathrm{KCl}, \mathrm{pH}$ 7.2) or by pretreating the brain slice with BAPTA/AM $(50-100 \mu \mathrm{M}$ with pluronic F-127 1\% for 2-6 hr). Drugs were applied in known concentrations by bath superfusion. Drug used were 5-HT creatinine sulfate, APV, BAPTA (Sigma Chemical Co.); BAPTA/AM, pluronic F-127 (Calbiochcm); 5-CT, 8-OH-DPAT, NAN-190, ( )bicucullinc, kctanserin (Research Biochemicals Inc.); CNQX (Cambridge Research Biochemicals).

Synaptic potentials or currents were evoked using focal electrical stimulation $(0.1-4 \mathrm{~mA}, 0.5 \mathrm{msec}$; single stimuli or trains as indicated at 40 $\mathrm{Hz}$ ) with bipolar tungsten electrodes placed within $500 \mu \mathrm{m}$ of the recording electrode. Note that trains of stimuli only approximate sustained release of 5-HT, because of feedback inhibition by 5-HT (Bobker and Williams, 1990). Therefore, while 20 stimuli at $40 \mathrm{~Hz}$ would trigger release for $500 \mathrm{msec}$, the concentration of $5-\mathrm{HT}$ is likely declining during the train. For the measurement of the sAHP, cells were held at -70 

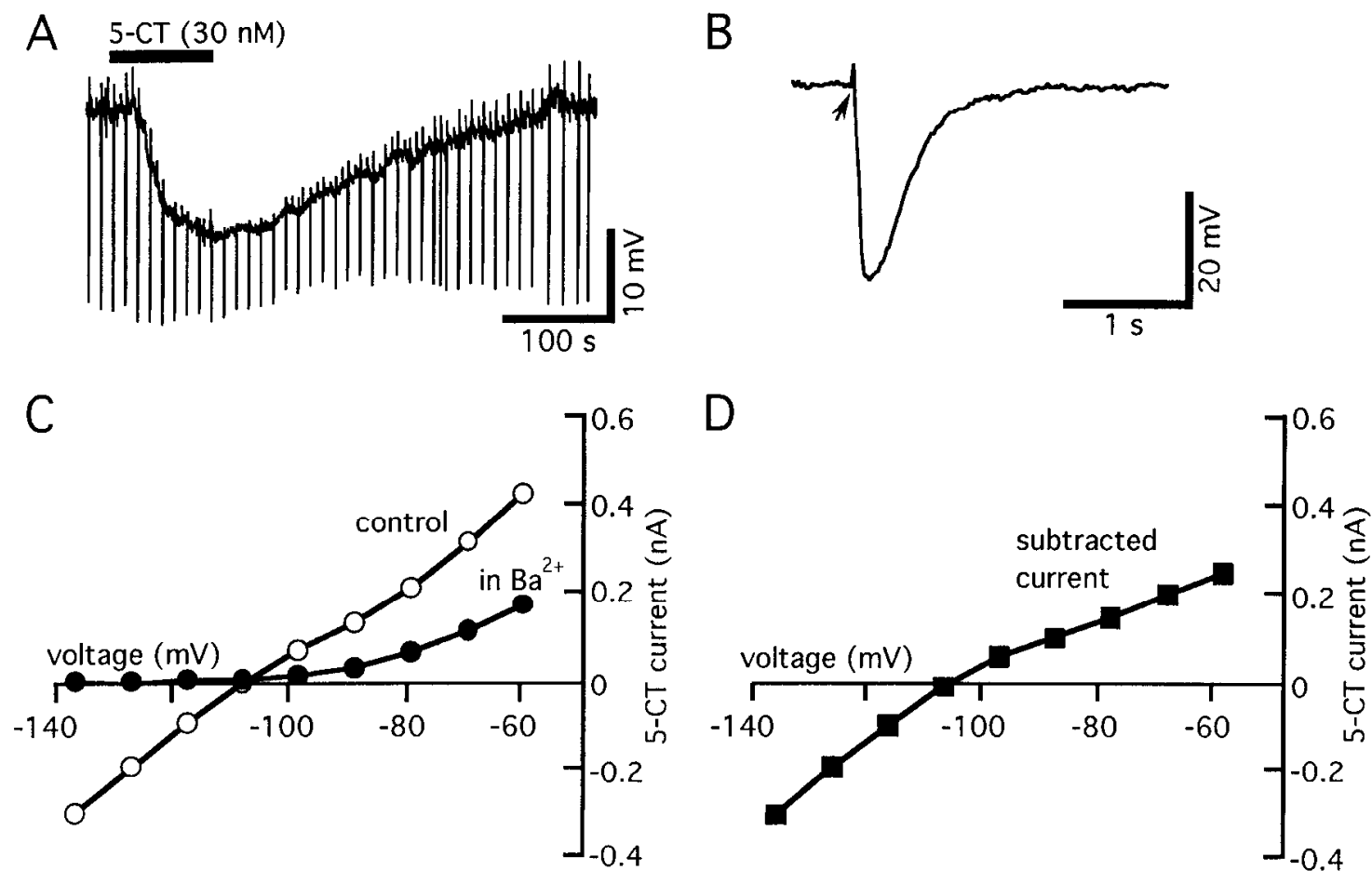

Figure 1. 5-CT activated two separate $\mathrm{K}^{+}$conductances. A, Bath application of 5-C.T ( $30 \mathrm{nM}$, indicated by bar) caused a membrane hyperpolarization. The fast pulses were electrotonic potentials (evoked by $500 \mathrm{msec}, 100 \mathrm{pA}$ current pulses) that demonstrate the associated decrease in input resistance. Holding potential was $-70 \mathrm{mV}$. B, Focal electrical stimulation (at arrow) caused a 5-HT-mediated IPSP with a duration of about 1 sec (Bobker and Williams, 1990). $C$, Under voltage clamp, the steady state $I / V$ relationship for 5-CT $(0.1 \mu \mathrm{M})$ in control (open circles) had inflection points at -110 and $-80 \mathrm{mV}$. Adding $\mathrm{Ba}^{2+}(0.2 \mathrm{mM}$; solid circles) to the perfusing solution blocked all 5 -CT current negative to about $-90 \mathrm{mV}$, leaving an outwardly rectifying current. Currents measured at the end of a $2 \mathrm{sec}$ step, with a holding potential of $-90 \mathrm{mV}$. Baseline currents (those present before the addition of agonist) have been subtracted. $D$, The control 5-CT current minus that in $\mathrm{Ba}^{2+}$ (from data in $C$ ) is shown (solid squares). This current rectified inwardly.

$\mathrm{mV}$ and action potentials were evoked with a $1.5 \mathrm{msec}$ depolarizing current pulse; four consecutive spikes were digitally averaged on Scope (ADInstruments)

Data analysis. Agonist-induced currents were determined by subtracting the baseline currents from those obtained in the presence of agonist. An exception was TEA $+(126 \mathrm{~mm})$, which activated $I_{\mathrm{OR}}$ itself, most probably by releasing endogenous 5 -HT. Therefore, the baseline currents were obtained by blocking the 5-HT current with NAN-190 $(1 \mu \mathrm{M})$; the current remaining was subtracted from that obtained with 5 -HT in the presence of TEA ${ }^{+}$. All subtractions were done directly with the digitized data. Exponential curve fitting was done using the Chebyshev algorithm with a double exponential and an added constant (AXOGRAPH, Axon Instruments, CA). The significance of differences between means was determined using Student's $t$ test. All mean values are expressed as the SEM.

\section{Results}

Selection of cells

Three cell types can be distinguished in the PH. Briefly, type I PH neurons had a fast action potential (about $0.5 \mathrm{msec}$ ), were spontaneously active (firing frequencies from 1 to $20 \mathrm{~Hz}$ ) and were found within $500 \mu \mathrm{m}$ of the wall of the fourth ventricle. Application of 5-HT to these cells caused a hypcrpolarization followed by a late depolarization. Focal electrical stimulation caused an IPSP (Fig. 1) and a slow EPSP, both mediated by 5-HT (Bobker and Williams, 1990; Bobker, 1994). Type II neurons had a broader action potential, were hyperpolarized by 5-HT and were located in the most rostral region of the nucleus. Type III neurons were also spontaneously active with a fast action potential and were located from 300 to $1000 \mu \mathrm{m}$ from the ventricular wall. 5-HT depolarizes these neurons by acti- vating h-current (Bobker and Williams, 1989). This study included type I cells only, which could be selected on the basis of their location close to the ventricle and their response to 5-HT.

\section{Ionic currents caused by applied agonists}

The ionic mechanism of the IPSP was characterized with current- and voltage-clamp studies using intracellular recordings from neurons in the slice preparation, as has been described previously (Bobker and Williams, 1990). Recordings were made from 65 type I PH neurons. Superfusion of 5-HT (10-100 $\mu \mathrm{M})$ caused a membrane hyperpolarization that ranged from 10 to $35 \mathrm{mV}$ and was associated with a decrease in input resistance. Because 5-HT also produced a late depolarization via $5-\mathrm{HT}_{2}$ receptors (Bobker, 1994), it was applied in the presence of the $5-\mathrm{HT}_{2}$ antagonist ketanserin. In some experiments, the selective $5-\mathrm{HT}_{1}$ agonist 5-carboxamidotryptamine (5-CT) or the $5-\mathrm{HT}_{1 \mathrm{~A}}$ agonist 8-hydroxy-2-(di- $n$-propylamino)-tetralin (8-OH-DPAT) was used because they caused a hyperpolarization only (Fig. 1A).

Under voltage clamp, 5-HT $(30 \mu \mathrm{M})$ in ketanserin $(1 \mu \mathrm{M})$, 5-CT $(0.1 \mu \mathrm{M})$, or 8-OH-DPAT $(0.1 \mu \mathrm{M})$ caused currents with an identical current/voltage $(I / V)$ relationship. The steady-state $I / V$ for 5-CT demonstrated an outward current at $-60 \mathrm{mV}$ that reversed polarity at $-103 \pm 1 \mathrm{mV}(n=9$; in another four cells the current did not reverse with steps to $-130 \mathrm{mV}$ ). The current was nonlinear; inflection points were observed at about -110 and $-80 \mathrm{mV}$. To determine if this $I / V$ relationship was due to the presence of two distinct currents, $\mathrm{Ba}^{2+}(0.2 \mathrm{mM})$ was added 
A

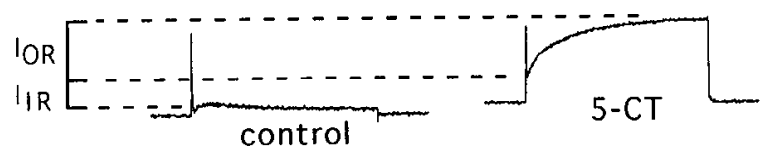

$B$

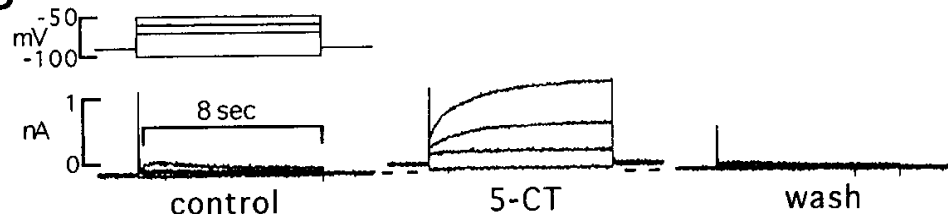

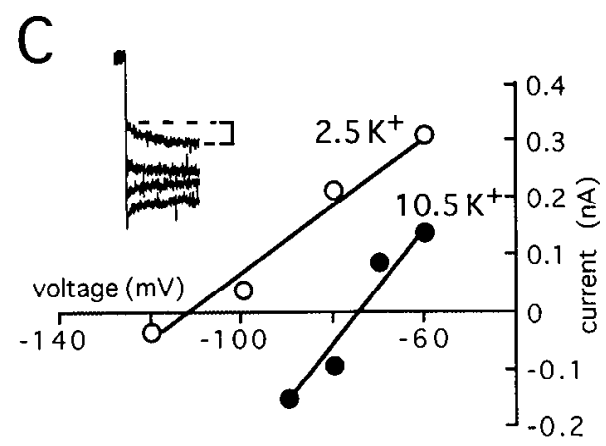

Figure 2. The two currents caused by 5-CT had different time courses. $A$, Under voltage clamp, a step command to $-50 \mathrm{mV}(8 \mathrm{sec}$ duration, $\left.V_{\text {hold }}=90 \mathrm{mV}\right)$ evoked a small outward current in control. Applying 5-CT $(0.1 \mu \mathrm{M})$ caused an increase in the instantaneous conductance and a slowly activating current relaxation. The instantaneous current was blocked by $\mathrm{Ba}^{2+}(0.2 \mathrm{~mm}$; data not shown $)$ and therefore corresponded to the inward rectifier $\left(I_{\mathrm{IR}}\right)$. The slowly activating current was the outward rectifier $\left(I_{\mathrm{OR}}\right)$. The perfusing solution contained tetrodotoxin (TTX; $0.2 \mu \mathrm{M}$ ), $\mathrm{Cs}^{+}(1 \mathrm{mM})$ and TEA ${ }^{+}(10 \mathrm{~mm})$. Dashed lines indicate the points of current measurement. B:Top trace, voltage protocol. Bottom three traces, currents are shown overlapped in control, 5-CT $(0.1 \mu \mathrm{M})$ and after 5-CT washout (same cell as in $A$ ). $I_{\mathrm{OR}}$ is only seen in the steps positive to -80 $\mathrm{mV}$. The dashed line indicates the holding current of $-0.15 \mathrm{nA} . C$, To demonstrate that $I_{\mathrm{OR}}$ was a $\mathrm{K}^{+}$current, tail currents were measured using hyperpolarizing steps ( $V_{\text {hold }}=-40 \mathrm{mV}, 3 \mathrm{sec}$ duration). 5-CT $(0.1 \mu \mathrm{M})$ has been applied. Cs ${ }^{+}(1 \mathrm{mM})$ and TTX $(0.2 \mu \mathrm{M})$ were present in the perfusing solution. With a $[\mathrm{K}+]_{0}$ of $2.5 \mathrm{~mm}$ (open circles), the current relaxations reverse polarity at $-112 \mathrm{mV}$. Increasing $\left[\mathrm{K}^{+}\right]_{o}$ to $10.5 \mathrm{~mm}$ shifted the reversal potential to $-76 \mathrm{mV}$ (solid circles). Inset, Traces of the 5-CT current (baseline currents subtracted; steps to $-60,-70,-80$, and -90 $\mathrm{mV}$ ) used to construct the $I / V$ at $10.5 \mathrm{mM}\left[\mathrm{K}^{+}\right]_{o}$, with $I_{\mathrm{OR}}$ measured as indicated by the bracket.

to the perfusing solution because it is known to inhibit $I_{\mathrm{IR}}$. This blocked the 5 -CT current negative to $-90 \mathrm{mV}$, leaving only an outwardly rectifying current $(n=7 ;$ Fig. $1 C)$. By subtracting the $\mathrm{Ba}^{2+}$-resistant current from the total current, the current blocked by low $\mathrm{Ba}^{2+}$ concentrations was revealed (Fig. $1 D$ ). This had the appearance typical of an inwardly rectifying $\mathrm{K}^{+}$current. Higher concentrations of $\mathrm{Ba}^{2+}(2 \mathrm{~mm})$ blocked the outwardly rectifying 5-CT current by greater than $90 \%(n=3)$.
Analysis of individual voltage steps demonstrated that the two currents could also be separated on the basis of time course. Depolarizing and hyperpolarizing voltage commands were made from a holding potential of $-90 \mathrm{mV}$ (from 2 to $8 \mathrm{sec}$ in duration). Superfusion of 5-CT had two effects on membrane properties. First, there was an increase in cell conductance evident immediately after a voltage step (Fig. $2 A$ ). This current reversed at the potassium equilibrium potential, rectified inwardly and
A

$$
\text { in } 5-\mathrm{HT}(30 \mu \mathrm{M})
$$
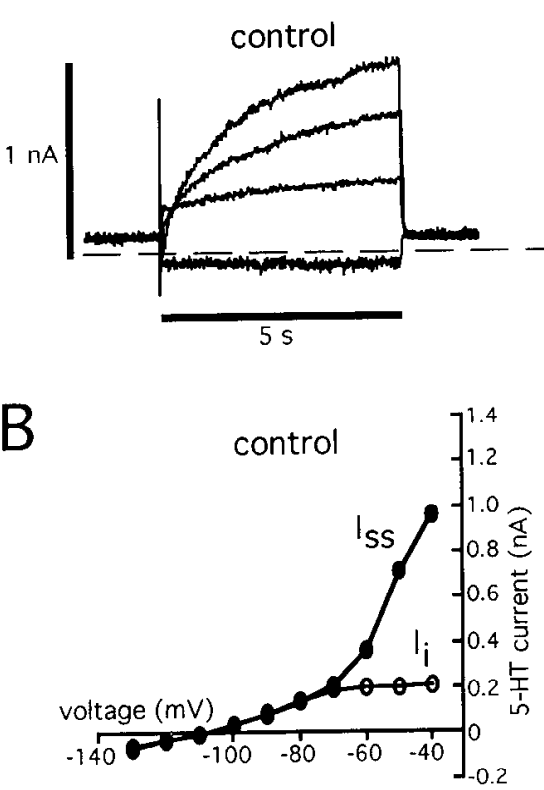
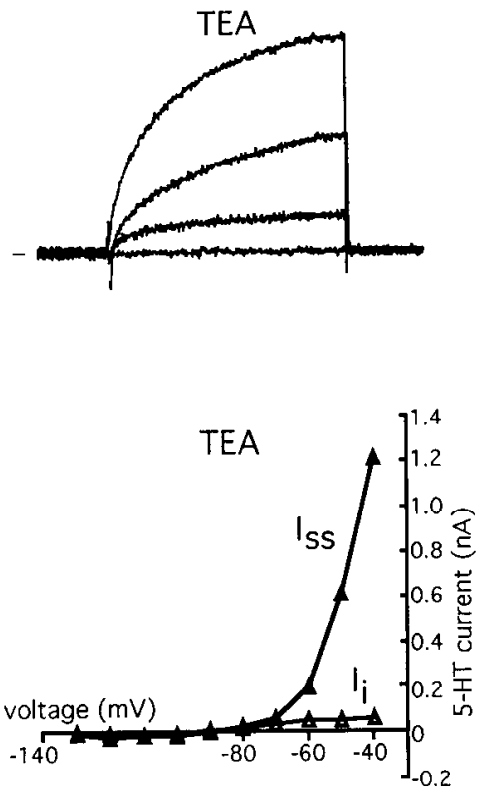
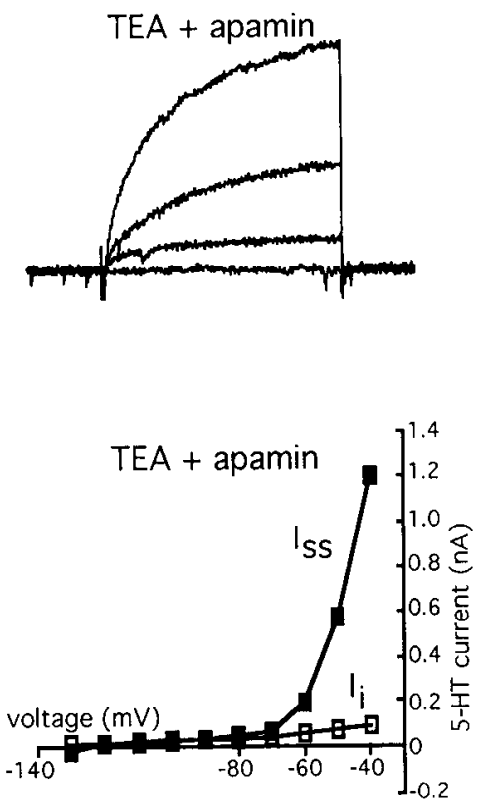

Figure 3. $\mathrm{I}_{\mathrm{OR}}$ is $\mathrm{TEA}^{+}$- and apamin insensitive. $A$, Currents caused by $5-\mathrm{HT}$ ( $30 \mu \mathrm{M}$, in ketanserin) are shown overlapped in control, in the presence of $\mathrm{TEA}^{+}\left(126 \mathrm{~mm}\right.$ in $\mathrm{Na}^{+}$-substituted media) and TEA ${ }^{+}$with apamin (100 nM). TEA ${ }^{+}$blocked the instantaneous current caused by 5 -HT, but caused no change in the slow outward current. Apamin had no effect on either current. $\mathrm{Cs}^{+}(2 \mathrm{mM})$ and TTX $(0.2 \mu \mathrm{M})$ were present throughout the experiment. Baseline currents have been subtracted. Dashed line represents 0 current. All data from a single cell. $B, I / V$ curves are shown for the corresponding traces above them in $A$. The instantaneous current $\left(I_{i}\right.$, open symbols $)$ was measured at the beginning of the step and the steadystate current $\left(I_{s s}\right.$, solid symbols) was measured at the end. 


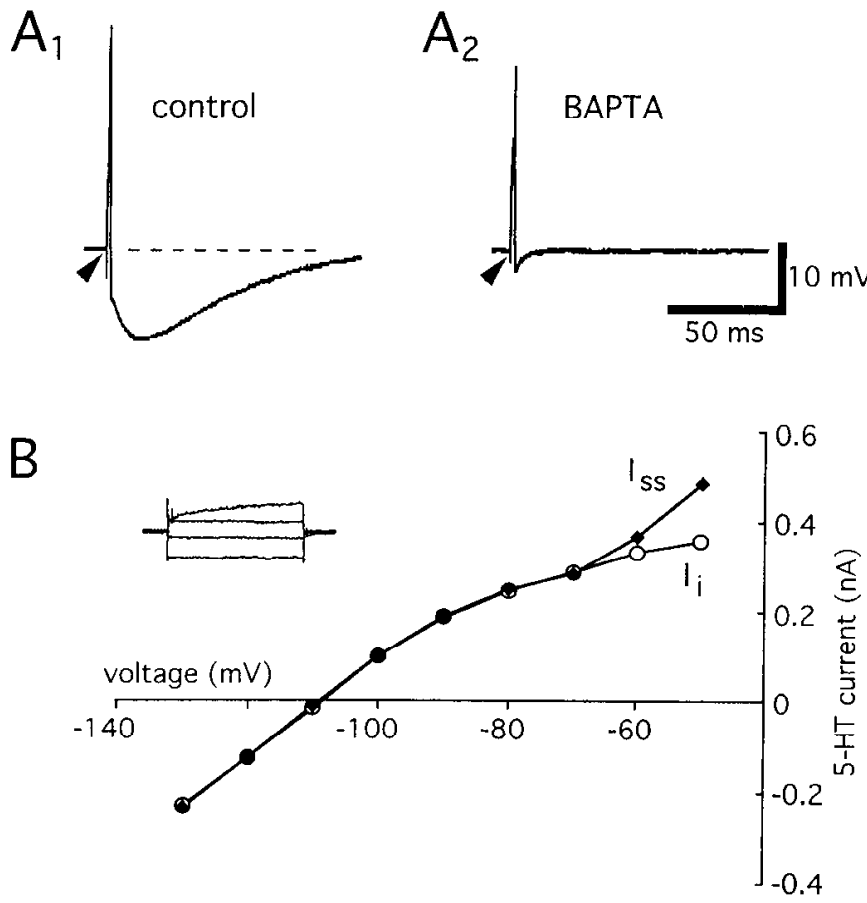

Figure 4. BAPTA inhibited $I_{\mathrm{OR}} \cdot A_{l}$, The effectiveness of intracellular BAPTA delivery was assessed by measurement of the SAHP. In a control cell, the sAHP is $16 \mathrm{mV}$. Dashed line represents holding potential of $-70 \mathrm{mV}$. The action potential has been truncated, and the trace is the average of four consecutive spikes. $A_{2}$, In a cell impaled with a BAPTAfilled electrode $(100 \mathrm{mM})$, the sAHP was nearly blocked after $15 \mathrm{~min}$. $B, I / V$ curve from another cell impaled for $15 \mathrm{~min}$ with a BAPTA-filled electrode ( $50 \mathrm{~mm}) .5-\mathrm{HT}(30 \mu \mathrm{M}$, with ketanserin) has been applied. The instantaneous current $\left(I_{i}\right.$, open circles) reversed at $-110 \mathrm{mV}$ and rectified inwardly. The steady-state current $\left(I_{s s}\right.$, solid diamonds) still had a slow outward component, but it is markedly reduced as compared with control cells. Inset, Representative steps at $-50,-70,-100$, and $-120 \mathrm{mV}$ are shown $\left(V_{\text {hold }}=-90 \mathrm{mV}, 5 \mathrm{sec}\right.$ duration). Baseline currents have been subtracted.

was blocked by $\mathrm{Ba}^{2+}(0.2 \mathrm{mM})$. Second, 5-CT caused a slowly developing outward current relaxation that was noninactivating. This time-dependent current caused the outward rectification seen with low $\mathrm{Ba}^{2+}(0.2 \mathrm{mM})$ and will be termed $I_{\mathrm{OR}} . I_{\mathrm{OR}}$ was first apparent in the steps made positive to $-80 \mathrm{mV}$ (Fig. $2 B$ ); its amplitude was $63 \pm 25 \mathrm{pA}$ at $-70 \mathrm{mV}$ and $779 \pm 74 \mathrm{pA}$ at $-40 \mathrm{mV}(n=6)$.

The reversal potential of $I_{\mathrm{OR}}$ was determined by using a tailcurrent protocol. In the presence and absence of 5-CT, hyperpolarizing steps $\left(V_{\text {hold }}=-40 \mathrm{mV}\right)$ were made to measure the decay of $I_{\mathrm{OR}}$. Current reversal occurred at $-100 \pm 3 \mathrm{mV}$ in 2.5 $\left[\mathrm{K}^{+}\right]_{,},\left(n=6\right.$, with two cells not reversing). Increasing $\left[\mathrm{K}^{+}\right]_{0}$ to $10.5 \mathrm{~mm}$ shifted the reversal to $-69 \pm 4 \mathrm{mV}(n=3$; Fig. $2 C)$. This shift was close to what would be predicted by the Nernst equation for a $\mathrm{K}^{+}$conductance.

\section{Effects of $\mathrm{K}^{+}$channel blockers}

As indicated above, extracellular $\mathrm{Ba}^{2+}$ at low concentration $(0.2$ $\mathrm{mM}$ ) blocked $I_{\mathrm{IR}}$, while high concentration $(2 \mathrm{mM})$ blocked $I_{\mathrm{OR}}$. Tetraethylammonium chloride (TEA ${ }^{+} ; 126 \mathrm{mM}^{\text {in }} \mathrm{Na}^{+}$-substituted media) was found to provide the best separation of the currents, as it had no effect on $I_{\mathrm{OR}}$ while causing a near complete block of $I_{\mathrm{IR}}(n=4$; Fig. 3$)$. TEA did cause the release of some endogenous 5-HT, however, as indicated by the appearance of
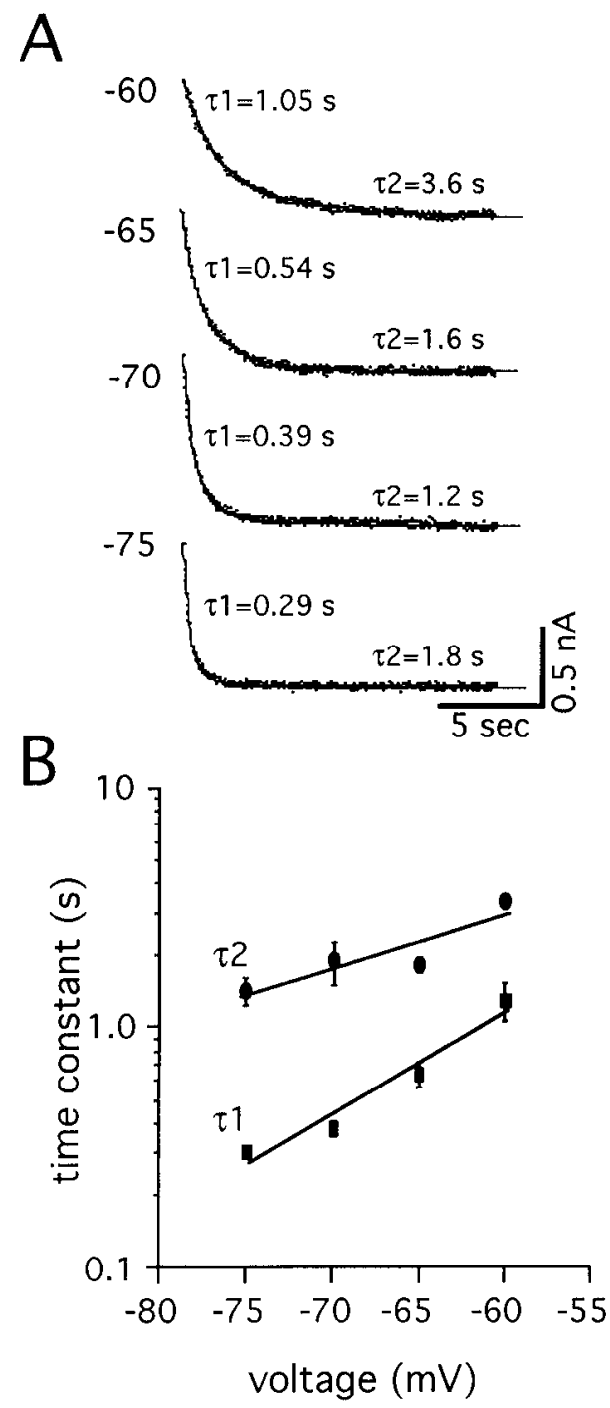

Figure 5. Deactivation kinetics of $\mathrm{I}_{\mathrm{OR}} . A$, In 5-HT (30 $\mu \mathrm{M}$, with ketanserin), tail currents are shown (only the time-dependent component) for steps to the indicated potential ( $V_{\text {nold }}=-50 \mathrm{mV}, 15 \mathrm{sec}$ duration). The double exponential curve fit is superimposed (solid line) and was used to determine time constants $\tau_{1}$ and $\tau_{2}$ (indicated next to each curve). All data from a single cell. $\mathrm{Cs}^{+}(1 \mathrm{~mm})$ was present in the perfusant. $B$, Semilogarithmic plot of time constant versus membrane potential. Data are averaged from three cells. Error bars are the SEM and are not shown when they fell within the data symbol.

$I_{\mathrm{OR}}$ before the application of 5-HT. Baseline currents for subtraction were therefore obtained by applying the $5-\mathrm{HT}_{1 \mathrm{~A}}$ antagonist 1-(2-methoxyphenyl)-4-[4-(2-phthalimmido)butyl]piperazine (NAN-190; $1 \mu \mathrm{M}$; Glennon et al., 1988), which blocked both $I_{\mathrm{OR}}$ and $I_{\mathrm{IR}}(n=3)$. Other compounds that had no effect on $I_{\mathrm{OR}}$ were $\mathrm{Cs}^{+}(2 \mathrm{mM}), 4$-aminopyridine $(5 \mathrm{mM})$, and apamin (100 nM; Fig. 3). $I_{\mathrm{OR}}$ was blocked by internal $\mathrm{Cs}^{+}(1 \mathrm{M}$ in the recording electrode as $\mathrm{CsCl}$ )

\section{Calcium dependence}

The slow activation and voltage dependence of $I_{\mathrm{OR}}$ suggested possible calcium dependence. Superfusion of $\mathrm{CdCl}_{2}(100-500$ $\mu \mathrm{M}$ in phosphate-free media) caused a $78 \pm 11 \%$ reduction in $I_{\mathrm{OR}}$ at $-50 \mathrm{mV}(n=3)$. The effect of the calcium buffer BAPTA was then tested. Intracellular loading was achieved either by adding BAPTA to the microelectrode solution or by using the 
membrane-permeant BAPTA/AM. With either method, reduction of the slow afterhyperpolarization (sAHP) was used as a measure of effective loading. Treated neurons had a reduced sAHP, with a peak amplitude of $8.4 \pm 1.0 \mathrm{mV}(n=11)$; this compares with a control sAHP of $15.8 \pm 0.5 \mathrm{mV}(n=5, P<$ 0.01 ; Fig. 4A). However, their input resistance (100-200 M $\Omega$ ), spontaneous firing rates $(3-10 \mathrm{~Hz})$, and location within the slice were typical of type I PH neurons. 5-HT $(30 \mu \mathrm{M})$ applicd to BAPTA-loaded neurons caused an instantaneous current that reversed at $-98 \pm 8 \mathrm{mV}$ and rectified inwardly (Fig. $4 B$ ). In contrast, $I_{\mathrm{OR}}$ was completely absent in some cells and reduced in others; at $-50 \mathrm{mV}$, the amplitude of the slow current relaxation was $508 \pm 65 \mathrm{pA}$ in control cells $(n=6)$ and $55 \pm 32 \mathrm{pA}$ in BAPTA treated cells $(n=4, P<0.01)$.

\section{Kinetics of $\mathrm{I}_{O R}$}

$I_{\mathrm{OR}}$ activated slowly, reaching half-maximal amplitude in $1.2 \pm$ $0.2 \mathrm{sec}$ at $-50 \mathrm{mV}(n=5)$. Deactivation kinetics were determined using the tail protocol and $15 \mathrm{sec}$ long steps to allow the current to reach steady state. Current relaxations were obtained between -60 and $-75 \mathrm{mV}\left(V_{\text {hold }}=-50 \mathrm{mV}\right)$. The current deactivation had an early fast decay followed by a later slow decay. An exponential curve fitting algorithm closely approximated thesc rclaxations using the sum of two exponential functions (Fig. 5A), while it could not do so with a single exponential. At $-60 \mathrm{mV}$, the resulting time constants for $\tau_{1}$ (fast decay) and $\tau_{2}$ (slow decay) were $1.3 \pm 0.2$ and $3.4 \pm 0.2 \mathrm{sec}$, respectively $(n=3)$. Both time constants were voltage-dependent, with an $e$-fold change occurring in $10 \mathrm{mV}$ for $\tau_{1}$ and in $20 \mathrm{mV}$ for $\tau_{2}$ (Fig. 5B).

\section{Ionic currents underlying the IPSP}

Having determined that $5-\mathrm{CT}$ (as well as $5-\mathrm{HT}$ and $8-\mathrm{OH}$ DPAT) activated two $\mathrm{K}^{+}$currents, we investigated which currents were responsible for generating the IPSP. A single electrical stimulus near the impaled neuron caused a 5-HT-mediated IPSP with a duration of $1 \mathrm{sec}$ and a peak amplitude of 10-35 $\mathrm{mV}$ occurring at about $200 \mathrm{msec}$ (Bobker and Williams, 1990). In voltage clamp, the inhibitory postsynaptic current (IPSC) amplitude ranged from 200 to $600 \mathrm{pA}$ and peaked at $207 \pm 7$ $\operatorname{msec}(n=5$; at $-55 \mathrm{mV})$. The IPSC reversed polarity at -109 $\pm 3 \mathrm{mV}$ in $2.5 \mathrm{~mm}\left[\mathrm{~K}^{+}\right]_{o}(n=3)$. The reversal of the IPSC suggested that at least a component of the current was due to $I_{\mathrm{IR}}$, as $I_{\mathrm{OR}}$ does not pass inward current under these conditions. We hypothesized that if $I_{\mathrm{IR}}$ was the only current contributing to the IPSC, then low concentrations of $\mathrm{Ba}^{2+}$ should completely block the IPSC. Instead, $\mathrm{Ba}^{2+}(0.2 \mathrm{~mm})$ caused most of its inhibition at more negative potentials, effectively blocking the reversal of the IPSC (Fig. $6 A$ ). At $-55 \mathrm{mV}$, the IPSC amplitude was $410 \pm 95 \mathrm{pA}$ in control and $323 \pm 113 \mathrm{pA}$ in $\mathrm{Ba}^{2+}$ (difference not significant); at $-125 \mathrm{mV}$, amplitudes were $-213 \pm$ $55 \mathrm{pA}$ in control and $-3 \pm 3 \mathrm{pA}$ in $\mathrm{Ba}^{2+}(P<0.05, n=3)$. A plot of IPSC amplitude versus voltage (IPSC $/ V$ ) in the presence and absence of $\mathrm{Ba}^{2+}$ (Fig. $6 \mathrm{~B}$ ) therefore recapitulated the $I / V$ curve of 5-CT under those conditions (see Fig. 1C).

A second prediction, based on the slow activation of $I_{\mathrm{OR}}$, was that longer exposures to transmitter should activate more of $I_{\mathrm{OR}}$ and increase the amplitude of the IPSC. Trains of stimuli (310 pulses) at $40 \mathrm{~Hz}$ were used to create a long "burst" of 5-HT release (see methods). Figure $7 A$ shows IPSCs evoked at two potentials. After holding the cell at $-50 \mathrm{mV}$ for at least $10 \mathrm{sec}$, a single stimulus or a train of stimuli were delivered. The train
A

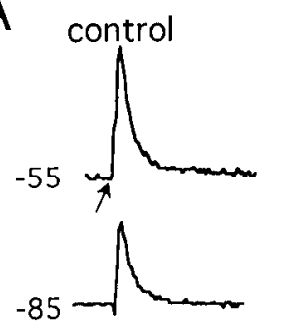

-125 mprom
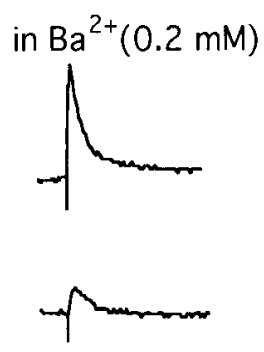

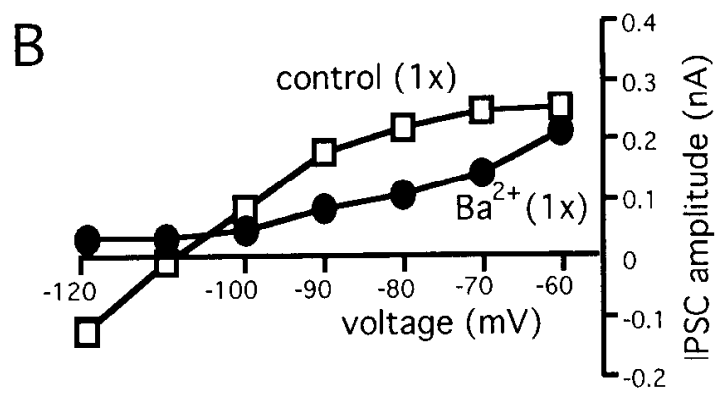

Figure 6 . Both $I_{\mathrm{OR}}$ and $I_{\mathrm{IR}}$ contribute to the IPSC. $A$, In voltage clamp, IPSCs were evoked with a single stimulus (at arrow, shown in first trace only) from three different potentials as indicated. In control, the reversal of the IPSC occurred at about $-110 \mathrm{mV}$. $\mathrm{Ba}^{2} \mid(0.2 \mathrm{~mm})$ reduced the amplitude of the IPSC primarily at more negative potentials and prevented its reversal. The brief downward deflections are stimulation artifacts. These experiments were done in the presence of 6-cyano-7nitroquinoxaline-2,3-dione (CNQX; $10 \mu \mathrm{M}$ ), 2-amino-5-phosphonovalerate (APV; $10 \mu \mathrm{M})$ and $(-)$ bicuculline $(10 \mu \mathrm{M})$, because $\mathrm{Ba}^{2+}$ caused some spontaneous glutamatergic and GABAergic synaptic potentials. $B$, In another cell, the same type of experiment was performed to construct an IPSC $/ V$ curve (control, open squares; in $\mathrm{Ba}^{2+}(0.2 \mathrm{mM})$, solid circles).

caused an augmentation of the IPSC that increased with the number of stimuli. At a holding potential of $-90 \mathrm{mV}$, where $I_{\mathrm{OR}}$ is inactive, no augmentation of the IPSC was seen with multiple stimuli. This resulted in a voltage-dependent augmentation that closely followed the voltage dependence of $I_{\mathrm{OR}}$ (Fig. $7 B$ ). This experiment supports the idea that $I_{\mathrm{OR}}$ contributes to the IPSC and can significantly augment it depending on the number of stimuli.

\section{Discussion}

This study demonstrates that in type I PH neurons bath applied 5 -HT or 5-CT activated two $\mathrm{K}^{+}$currents, $I_{\mathrm{IR}}$ and $I_{\mathrm{OR}}$. This is supported by the experiments with $\mathrm{TEA}^{+}$and BAPTA, showing selective blockade of $I_{\mathrm{IR}}$ and $I_{\mathrm{OR}}$, respectively. $I_{\mathrm{IR}}$ has properties similar to those described for classical $G$ protein-coupled inwardly rectifying $\mathrm{K}^{+}$currents: it activated rapidly and was sensitive to $\mathrm{Ba}^{2+}$ and $\mathrm{TEA}^{+}$. This finding is similar to what has been reported for the $5-\mathrm{HT}_{1 \mathrm{~A}}$ receptor in other brain regions (Andrade and Nicoll, 1987; Williams et al., 1988). However, the observation of a second $\mathrm{K}^{+}$conductance being activated by the $5-\mathrm{HT}_{\mathrm{IA}}$ receptor has not been reported. $I_{\mathrm{OR}}$ had properties that were quite distinct from $I_{\mathrm{IR}}$ : it activated slowly, rectified outwardly, and was much less sensitive to $\mathrm{Ba}^{2+}$. It is of interest to note that in rat $\mathrm{CA} 1$ hippocampal neurons, $\mu$-opioid receptors 

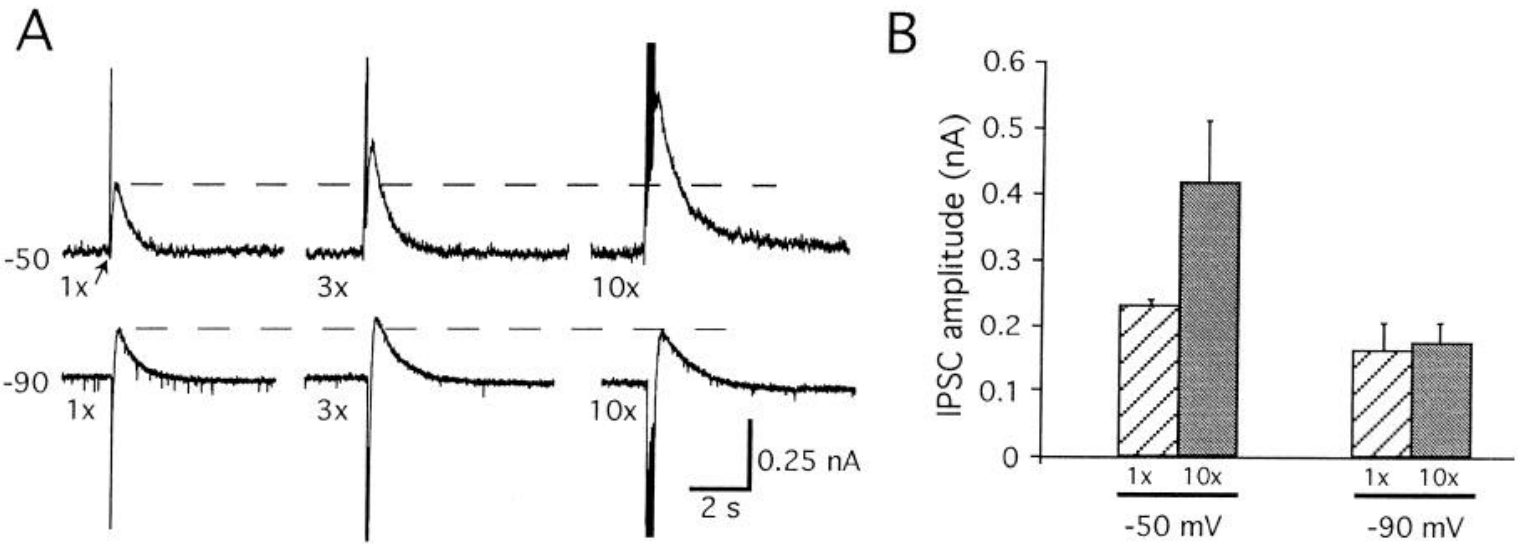

Figure 7. $I_{\mathrm{OR}}$ potentiated the IPSC. A, In the upper three traces, at $-50 \mathrm{mV}$ IPSCs were evoked (at arrow, indicated in first trace) using 1 (1 $\times$ ), $3(3 \times)$, or $10(10 \times)$ stimuli (supramaximal stimulus, train at $40 \mathrm{~Hz}$ ). Longer trains of stimuli increased the IPSC amplitude. Dashed line indicates the amplitude of the $1 \times$ IPSC for comparison. Fast upward deflections are stimulation artifacts. The lower three traces show same experiment conducted at $-90 \mathrm{mV}$. All traces from one cell. B, Averaged data from four cells showing the IPSC amplitude at -50 and $-90 \mathrm{mV}$. Hatched bars indicate the amplitude following a single stimulus; solid bars, for 10 stimuli. The IPSC amplitude was increased $(82 \pm 14 \%, P<0.05$, Student's $t$ test) by multiple stimuli at $-50 \mathrm{mV}$, while not being significantly affected at $-90 \mathrm{mV}$. Error bars indicate the SEM.

also activate inwardly and outwardly rectifying $\mathrm{K}^{+}$conductances (Wimpey and Chavkin, 1991). The latter current reported by these investigators was different from $I_{\mathrm{OR}}$ reported here, however. They described a current that activated rapidly, appeared only with strong depolarizations (positive to $-60 \mathrm{mV}$ ) and was insensitive to $\mathrm{Cd}^{2+}$. In addition, they did not observe inward and outward rectifiers occurring in the same cell. Therefore, $G_{i}$ coupled receptors may have the ability to activate a variety of $\mathrm{K}^{+}$conductances in different cell types.

Our experiments to characterize $I_{\mathrm{OR}}$ demonstrate that it has properties in common with both Ca-activated $\mathrm{K}^{+}$currents and the muscarine-sensitive M-current. The inhibition of $I_{\mathrm{OR}}$ by $\mathrm{Cd}^{2+}$ and intracellular BAPTA suggests that it is Ca dependent and may therefore belong to the former group. Furthermore, Ca-dependent $\mathrm{K}^{+}$channels often exhibit slow activation kinetics (Brown and Griffith, 1983; Lancaster and Adams, 1986; North and Tokimasa, 1987) and may be modulated by neurotransmitters (Trautmann and Marty, 1984; Lancaster and Adams, 1986). Arguing against this is its activation at relatively negative potentials and insensitivity to $\mathrm{TEA}^{+}$and apamin, inhibitors of BK and SK channels, respectively. However, as apamin-insensitive SK channels have been described, we cannot eliminate the possibility that $I_{\mathrm{OR}}$ is such a conductance (Latorre et al., 1989). In comparing $I_{\mathrm{OR}}$ with M-current, they are found to share a similar voltage dependence, display insensitivity to most $\mathrm{K}^{+}$ channel blockers and are both blocked by high concentrations of $\mathrm{Ba}^{2+}$ (Brown and Adams, 1980; Adams et al., 1982). External $\mathrm{Cd}^{2+}$ has been reported to inhibit M-current by some investigators (Tokimasa and Akasu, 1990), while others have not seen an effect (Adams et al., 1982; Madison et al., 1987). There are two important differences between $I_{\mathrm{OR}}$ and M-current, however. First, $I_{\mathrm{OR}}$ has significantly slower kinetics of activation and deactivation (Marrion et al., 1992). Second, $I_{\mathrm{OR}}$ appears to be dependent on agonist activation; in contrast, while M-current can be modulated by various transmitters (Brown and Adams, 1980; Moore et al., 1988; Sims et al., 1988), depolarization alone is sufficient for activation. In summary, the properties of $I_{\mathrm{OR}}$ are most consistent with a Ca-activated $\mathrm{K}^{+}$current. The source of $\mathrm{Ca}^{2+}$ could be voltage-dependent entry through calcium channels, as suggested by the $\mathrm{Cd}^{2+}$ inhibition of $I_{\mathrm{OR}}$. However, $\mathrm{Cd}^{2+}$ is known to have effects unrelated to channel blockade. In addition, the failure of $I_{\mathrm{OR}}$ to activate with depolarization alone argues against this possibility. A more likely source of $\mathrm{Ca}^{2+}$ then, would be receptor-mediated release from intracellular stores.

The pharmacological data indicates that the $5-\mathrm{HT}_{\mathrm{IA}}$ receptor is responsible for activating both $I_{\mathrm{IR}}$ and $I_{\mathrm{OR}}$. This is supported by the observation that 5-CT and 8-OH-DPAT activated both currents. Although 5-CT is an agonist at all 5-HT, receptors, 8-OH-DPAT is quite selective for the 5 - $\mathrm{HT}_{1 \mathrm{~A}}$ subtype (Gozlan et al., 1983). In addition, NAN-190 blocked both currents. With respect to second messengers, previous studies of the cloned human 5-HT ${ }_{1 \mathrm{~A}}$ receptor have demonstrated that it couples negatively to adenylate cyclase through a $\mathrm{G}_{i}$ protein (Fargin et al., 1989), as well as stimulating phospholipase $C$ and increasing cytosolic $\mathrm{Ca}^{2+}$ levels (Raymond et al., 1992). It also known that G proteins can directly activate some channels (Brown, 1990), including some inward rectifiers (Yatani et al., 1987; Kubo et al., 1993). Therefore, it is possible that $5-\mathrm{HT}_{1 \mathrm{AA}}$ receptor activation leads to a single second messenger that triggers two conductances or that distinct transducers are involved. Our experiments suggest that the pathway leading to $\mathrm{Ca}^{2+}$ release may be critical for evoking $I_{\mathrm{OR}}$.

A significant finding of this report was that both $I_{\mathrm{IR}}$ and $I_{\mathrm{OR}}$ contributed to generating the current that underlies the IPSP. Two lines of evidence support this contention. First, we demonstrated that superfusion of 5-CT and 5-HT activated the two conductances. There is no reason to anticipate that synaptically released 5-HT would not have a similar effect. Second, low concentrations of $\mathrm{Ba}^{2+}$ blocked $I_{\mathrm{IR}}$ during bath application of 5 -HT, with the remaining current being $I_{\mathrm{OR}}$. The same concentration of $\mathrm{Ba}^{2+}$ reduced the amplitude of the IPSC at more negative potentials and prevented its reversal. If the IPSC was mediated by $I_{\mathrm{IR}}$ alone, then $\mathrm{Ba}^{2+}$ should have caused a near complete inhibition of it. Instead, it revealed an IPSC/ $V$ curve that was similar to the $I / V$ for the outward rectifier. This indicates that the IPSC has components of each current.

In addition to contributing to generation of the IPSP, $I_{\mathrm{OR}}$ may serve to modulate its amplitude. In our experiments, we used a high frequency train of stimuli to cause a prolonged release of transmitter. This resulted in a voltage-dependent augmen- 
tation of the IPSC that closely followed the voltage-dependence of $I_{\mathrm{OR}}$. The IPSP amplitude may therefore be determined by a relatively constant input from $I_{\mathrm{IR}}$ and a variable input from $I_{\mathrm{OR}}$. This variation might be observed physiologically if the presynaptic neuron undergoes burst-firing. The findings presented here are significant then for two reasons. First, they indicate that a $\mathrm{K}^{+}$current other than $I_{1 \mathrm{~K}}$ can contribute to an IPSP. Second, this represents a manner by which neurotransmission may be potentiated at the postsynaptic membrane and suggests that one function of slowly activating currents may be regulation of the intensity of synaptic transmission.

\section{References}

Adams P, Brown DA, Constanti A (1982) Pharmacological inhibition of the M-current. J Physiol (Lond) 332:223-262.

Andrade R, Nicoll RA (1987) Pharmacologically distinct actions of serotonin on single pyramidal neurons of the rat hippocampus recorded in vitro. J Physiol (Lond) 394:99-124.

Bobker DH (1994) A slow excitatory postsynaptic potential mediated by $5-\mathrm{HT}_{2}$ receptors in nucleus prepositus hypoglossi. J Neurosci 14 : 2428-2434.

Bobker DH, Williams JT (1989) Serotonin augments the cationic current $I_{h}$ in central neurons. Neuron $2: 1535-1540$.

Bobker DH, Williams JT (1990) Serotonin-mediated inhibitory postsynaptic potential in guinea-pig prepositus hypoglossi and feedback inhibition by serotonin. J Physiol (Lond) 422:447-462.

Brown AM (1990) Ionic channels and their regulation by $\mathrm{G}$ protein subunits. Annu Rev Physiol 52:197-213.

Brown DA, Adams PR (1980) Muscarinic suppression of a novel voltage-sensitive $\mathrm{K}^{+}$current in a vertebrate neurone. Nature 283: 673-675.

Brown DA, Griffith WH (1983) Calcium-activated outward current in voltage-clamped neurones of the guinea-pig. J Physiol (Lond) 337: 287-301.

Del Castillo J, Katz B (1955) Production of membrane potential changes in the frog's heart by inhibitory nerve impulses. Nature 175:1035.

Dutar P, Nicoll RA (1988) A physiological role for $\mathrm{GABA}_{B}$ receptors in the central nervous system. Nature 332:156-158.

Egan T, Henderson G, North RA, Williams JT (1983) Noradrenalinemediated synaptic inhibition in rat locus coeruleus neurones. J Physiol (Lond) 345:477-488.

Fargin A, Raymond J, Regan J, Cotecchia S, Lefkowitz R, Caron M (1989) Effector coupling of the cloned 5-HT $\mathrm{T}_{1 \mathrm{~A}}$ receptor. J Biol Chem 264:14848-14852.

Glennon RA, Naiman N, Pierson M, Titeler M, Lyon R, Wcisberg E (1988) NAN-190: an arylpiperazine analog that antagonizes the stimulus effects of the 5-HT ${ }_{\text {IA }}$ agonist 8-hydroxy-2-(di- $n$-propylamino)tetralin (8-OH-DPAT). Eur J Pharmacol 154:339-341.

Gozlan H, El Mestikawy S, Pichat L, Glowinski J, Hamon M (1983) Identification of presynaptic serotonin autoreceptors using a new ligand: ${ }^{3}$ H-PAT. Nature 305:140-142.

Hille B (1992) Potassium channels and chloride channels. In: Ionic channels of excitable membranes, pp 115-139. Sunderland, MA: Sinauer.
Kubo Y, Reuveny E, Slesinger PA, Jan YN, Jan LY (1993) Primary structure and functional expression of a rat G-protein-coupled muscarinic potassium channel. Nature 364:802-806.

Lancaster B, Adams PR (1986) Calcium-dependent current generating the afterhyperpolarization of hippocampal neurons. J Neurophysiol 55:1268-1282.

Latorre R, Oberhauser A, Labarca P, Alvarez O (1989) Varieties of calcium-activated potassium channels. Annu Rev Physiol 51:385399.

Madison DV, Lancaster B, Nicoll RA (1987) Voltage-clamp analysis of cholinergic action in the hippocampus. J Neurosci 7:733-741.

Marrion NV, Adams PR, Gruner W (1992) Multiple kinetic states underlying macroscopic $\mathrm{M}$-currents in bullfrog sympathetic neurons. Proc R Soc Lond [Biol] 248:207-214.

Mihara S, Nishi S, North RA, Surprenant A (1987) A nonadrenergic, noncholinergic slow inhibitory postsynaptic potential in neurones of the guinea-pig submucous plexus. J Physiol (Lond) 390:357-365.

Moore SD, Madamba SG, Joels M, Siggins GR (1988) Somatostatin augments the M-current in hippocampal neurons. Science 239:278280.

North RA (1989) Drug receptors and the inhibition of nerve cells. $\mathrm{Br}$ J Pharmacol 98:13-28.

North RA, Tokimasa T (1987) Persistent calcium-sensitive potassium current and the resting properties of guinea-pig myenteric neurones. J Physiol (Lond) 386:333-353.

Pan ZZ, Colmers WF, Williams JT (1989) 5-HT-mediated synaptic potentials in the dorsal raphe nucleus: interactions with excitatory amino acid and GABA neurotransmission. J Neurophysiol 62:481486.

Pennington NJ, Kelly JS (1990) Serotonin receptor activation reduces calcium current in an acutely dissociated adult central neuron. Neuron $4: 751-758$.

Raymond JR, Albers FJ, Middlemiss JP (1992) Functional expression of human 5-HT ${ }_{1 \mathrm{~A}}$ receptors and differential coupling to second messengers in CHO cells. Naunyn Schmiedebergs Arch Pharmacol 346: $127-137$.

Sims SM, Singer JJ, Walsh JV (1988) Antagonistic adrenergic-muscarinic regulation of M-current in smooth muscle cells. Science 239: 190-192.

Tokimasa T, Akasu T (1990) ATP regulates muscarine-sensitive potassium current in dissociated bull-frog primary afferent neurones. $J$ Physiol (Lond) 426:241-264

Trautmann A, Marty A (1984) Activation of Ca-dependent K channels by carbamoylcholine in rat lacrimal glands. Proc Natl Acad Sci USA 81:611-615.

Williams JT, Colmers WF, Pan ZZ (1988) Voltage- and ligand-activated inwardly rectifying currents in dorsal raphe neurons in vitro. J Neurosci 8:3499-3506.

Wimpey TL, Chavkin C (1991) Opioids activate both an inward rectifier and a novel voltage-gated potassium conductance in the hippocampal formation. Neuron 6:281-289.

Yatani A, Codina J, Brown AM, Birnbaumer L (1987) Direct activation of mammalian atrial muscarinic potassium channels by GTP regulatory protein $G_{k}$. Science 235:207-211. 